\title{
On the name of the lepidophagous characid fish Roeboexodon guyanensis (Puyo) (Teleostei: Characiformes: Characidae)
}

\author{
Cristiano R. Moreira ${ }^{1}$ and Flávio C. T. Lima ${ }^{2}$
}

The arguments for the usage of the names Gnathoplax, Roeboexodon, R. geryi, and R. guyanensis are revised. Based on the literature and museum specimens, we recommend that the neotype of Exodon guyanensis should be considered valid; that the genus Gnathoplax should be considered an objective junior synonym of Roeboexodon; and that Roeboexodon geryi should be considered an objective junior synonym of Exodon guyanensis.

Os argumentos para o uso dos nomes Gnathoplax, Roeboexodon, R. geryi e R. guyanensis são reavaliados. Baseados na literatura e em espécimes de museu, recomendamos que o neótipo de Exodon guyanensis seja considerado válido, que o gênero Gnathoplax seja considerado sinônimo objetivo júnior de Roeboexodon e que Roeboexodon geryi seja considerado sinônimo objetivo júnior de Exodon guyanensis.

Key words: Exodon, Gnathoplax, Nomenclature, Roeboexodon geryi.

Lucena \& Lucinda (in Lima et al., 2003) proposed that Roeboexodon guyanensis, a name applied to a lepidophagous characid of rivers draining the Guyana and Brazilian Shields, is a species inquirenda, and that the combination Roeboexodon geryi should be instead used. The reasoning of those authors and the literature are reviewed, and we find no evidence to consider Roeboexodon geryi as distinct from $R$. guyanensis. Thus, the neotype designed by Géry (1959) for $R$. guyanensis is considered valid, and $R$. guyanensis is the appropriate name for the species, with $R$. geryi as a junior synonym. Similarly, Gnathoplax is considered an objective synonym of Roeboexodon.

Puyo (1948) described a very distinct lepidophagous characid as Exodon guyanensis, based on three specimens from the Rivers Approuague and Maroni in French Guiana. He compared his new species with its only congener, the lepidophagous Exodon paradoxus from Guyana and concluded they were distinct. Puyo also provided a crude drawing of the head and the whole body of the new species.
Géry (1959) noted the incompleteness of Puyo's description (1948) and the absence of a type series (types are unknown for the freshwater fishes described by Puyo; Eschmeyer \& Fricke, 2009). Géry (1959) redescribed the species with material collected in French Guiana and described a new genus, Roeboexodon, for Puyo's species and illustrated the fish in more detail.

Later, Myers (1960) pointed several discrepancies between the descriptions by Puyo (1948) and Géry (1959). He considered the specimens that Géry (1959) used in the redescription as being non cospecific with Exodon guyanensis. For that reason, Myers (1960) erected a new genus, Gnathoplax, for Puyo's Exodon guyanensis, and considered Roeboexodon a valid genus, naming the species described by Géry (1959) as $R$. geryi, using Gery's $R$. guyanensis neotype (MNHN 1959-0038), as the holotype of R. geryi. Myers (1960) cited some morphological characters that he considered useful to distinguish the species described by Puyo from the one described by Géry.

${ }^{1}$ Departamento de Ciências Biológicas, Universidade Federal de São Paulo. Rua Professor Artur Riedel, 275, $9972-270$ Diadema, SP, Brazil. moreira.c.r@gmail.com

${ }^{2}$ Museu de Zoologia da Universidade de São Paulo. Caixa Postal 42494, 04299-970 São Paulo, SP, Brazil. fctlima@usp.br 
Neither Gnathoplax nor Roeboexodon geryi were considered valid by subsequent authors dealing with the species (Géry, 1977; Lowe-McConnell, 1991; Planquette et al., 1996), who instead simply used the name Roeboexodon guyanensis. Recently, Lucena \& Lucinda (in Lima et al., 2003; hereafter Lucena \& Lucinda, 2003), resurrected the controversy concerning these names. Following Myers (1960), Lucena \& Lucinda (2003) considered Roeboexodon geryi as the type species of Roeboexodon, by subsequent designation, and Gnathoplax and Exodon guyanensis as genus and species inquirenda in the Characidae, respectively. They present a two-fold justification for their conclusions. The first involves Myers' (1960) proposition that Puyo (1948) and Géry (1959) dealt with two separate species and genera. They also proposed that the neotype designated by Géry (1959) is not valid according to the International Code of Zoological Nomenclature.

Below, we examine in detail the justifications proposed by Myers (1960) and by Lucena \& Lucinda (2003), and conclude that, contrary to what these authors suggest, the correct type species of Roeboexodon is in fact R. guyanensis, with Gnathoplax and Roeboexodon geryi as objective synonyms of Roeboexodon, and Roeboexodon guyanensis, respectively.

Taxonomic issues. Myers (1960) pointed out that Géry (1959) overlooked most of the differences between the specimens he had in hand, and the description by Puyo (1948). Interestingly, Myers stated that the description by Puyo (1948) is not "particularly full" and he had "to take certain characters from the drawings [of Puyo], which are not as detailed as one would like" (Myers, 1960: 208). Based only on the descriptions and illustrations by Puyo (1948) and Géry (1959), he proposed several differences between Gnathoplax and Roeboexodon.

In the description of Exodon guyanensis, Puyo (1948) did not mention the position of the maxilla, however, the illustration seems to indicate that the bone lies lateral to and covers the first, and apparently also the second infraorbital bones. Géry (1959), in contrast, described and illustrated the maxilla as lying medial to the infraorbitals. In the material examined, the maxilla of Roeboexodon has an indentation along its dorsolateral half, into which the first infraorbital fits when the mouth is closed, which makes it difficult to distinguish the limits between these two bones. The illustration by Puyo (1948) inaccurately shows a maxilla that is actually a composite of the maxilla and the first infraorbital. The medial position of the maxilla relative to the infraorbitals explains Myers (1960: 209) statement that Puyo (1948: fig.1) shows the dorsal margin of the maxilla as "excised" to accommodate the eye. This detail is not shown by Géry (1959), because it rather corresponds to the concave dorsal margin of the first infraorbital.

Puyo (1948) only reported lateral line and transverse scale counts. Puyo cited 12 scales below the lateral line, whereas Géry (1959) reported seven to eight. We believe that this difference is due to alternative modes in which the scales were counted. Puyo (1949: 18) followed Günther (1859), who counted transverse scales from the scale immediately anterior to the dorsal fin obliquely to and including the median abdominal row of scales. Thus, it is likely Puyo (1948) counted the scales from lateral line (including it or not) to the median abdominal row of scales. Géry (1959), in contrast, counted the scales from the lateral line to the pelvic fin (probably anterior to its insertion). The different methods of counting the scales can add two or three scales to the count reported by Géry (1959), a number much closer to the one reported by Puyo (1948), thereby explaining the discrepancy pointed by Myers (1960).

Myers (1960: 209-300) suggested that the dorsal fin is situated more anteriorly in Gnathoplax than in Roeboexodon. In Puyo's illustration, the origin of the dorsal is slightly anterior to the middle of the standard length. Géry (1959) stated that the dorsal fin "is placed approximately at middle of body (caudal not included), slightly closer to the snout than to the terminus of the caudal peduncle" (Géry, 1959: 350). Comparing the proportions of the predorsal length versus SL on the drawings by Géry and Puyo reveals a slight difference between Puyo's (1948) and Géry's (1959) data (2.3 vs. 2.0, respectively). The material examined from French Guiana and Suriname by us and by Lucena \& Lucinda (2004) ranges between 1.91 to 2.13. Despite of this not reaching Puyo's proportion, it must be taken into account that this measurement was taken not from a specimen but actually from the very crude drawing provided by Puyo (1948), making this small difference into something actually irrelevant.

Myers (1960) noted a difference in eye size in Puyo's (1948) and Géry's (1959) descriptions. He noted that Puyo (1948) stated the "eye [is] very large, larger than the humeral spot, its diameter almost equal to depth of caudal peduncle and contained about 3.5 times in the greatest body depth" (Myers, 1960: 209), whereas Géry (1959) reported the "eye [is] of moderate size, equal to or smaller than the humeral spot, its diameter much less than the depth of the caudal peduncle, and contained about 4 times in the greatest body depth" (Myers, 1960: 210). Nonetheless, Puyo (1948: 78) mentioned that the eye diameter is "shorter than snout length and contained three times two-thirds in the head length" (i.e., 3.7 times in the head length). Since, according to Puyo, the head length equals the body depth, the eye diameter is contained approximately 3.7 times in the body depth, contra the 3.5 stated by Myers (1960). From the description of Géry (1959) the body depth is approximately 4 times the eye diameter. These values fall within the range of variation in the examined material (2.8 to 4.2$)$. The differences in eye size compared to the humeral spot that Myers (1960) mentioned are not apparent. The eye limits in Puyo's (1948) illustration are hard to distinguish. However, the eye diameter shown by Puyo and Géry are approximately the same size as the humeral spot, and smaller than the caudal peduncle depth. 
The upper jaw was reported by Puyo (1948) to possess four to six teeth apart from the plate of small teeth and the horizontallydirected tooth at the tip of the snout. According to Géry (1959), his specimens possessed four teeth on the premaxilla, and seven teeth on the maxilla. The arrangement of the upper jaw teeth in Roeboexodon guyanensis is very distinct from that of most Characiformes. Of the four premaxillary teeth, only the posteromesial one is placed in a position similar to other Characiformes. Two smaller teeth are placed laterally on the snout, and a large anterior most tooth is placed on the tip of the snout. On the maxilla, at least three teeth are directed inwards, one of which is lateral to the medial premaxillary teeth, the other two being more posterior and displaced towards the inner face of the maxilla. These posterior two teeth are inconspicuous, and easily overlooked. Three other maxillary teeth are situated ventrally, similar to the condition in most Characiformes, and an additional tooth is displaced to the lateral face of the maxilla. If the two inconspicuous inner posterior maxillary teeth are overlooked, the total count is six, which fits the counts given by Puyo (1948). The count of four teeth also given by Puyo (1948) was very probably merely a consequence of counting only the outer maxillary tooth, and the three normally positioned maxillary teeth.

Myers (1960) stated that the descriptions of Puyo (1948) and Géry (1959) differed in the position of the humeral spot, closer to the head than to the origin of the dorsal fin in the latter, and the size of the caudal spot, larger than the humeral spot in the former. These differences are indeed present between the illustrations of both authors. However, the position of the humeral spot can be evaluated in terms of position along the lateral line scales. Puyo (1948: 80) stated that the humeral spot is "at the level of the eighth or ninth lateral line scale," while Géry (1959:351) stated that it is "placed posteriorly to the 4-5 scales posterior to the opercle". Apparently, Puyo (1948) refers to where the spot is situated (probably the central scale), whereas Géry (1959) apparently refers to where the spot commences. In fact, Géry (1959: fig.1) illustrated the spot as extending from the $6^{\text {th }}$ to the $10^{\text {th }}$ scale, encompassing the range given by Puyo (1948). The small difference pointed out by Myers (1960) on the size of the humeral spot compared to the caudal spot could be, again, simply ascribed to the inaccuracy of Puyo's illustration (1948).

Myers (1960) stated that the specimens described by Puyo (1948) are conspicuously more elongated than the specimens examined by Géry (1959). According to Puyo (1948: 78) in the specimens he examined, the head length was equal to the body depth. This is actually similar to the data given by Géry (1959) where body depth is 3.2 to 3.45 in SL and head length is 3.4 to 3.6 in SL with comparable range found in the material examined in this study.

Puyo described and illustrated a "brush- or velvet-like tooth plate" on the maxilla and dentary (Puyo, 1948: 78). Tooth plates were not observed by Géry (1959), who commented that this was probably a mistake by Puyo (1948). We agree with this view, since teeth plates are unknown among Characiformes, and no similar structure was observed even in the smallest specimen examined herein (19.5 mm SL).
Notwithstanding Myers' suppositions on the contrary, only one species fitting Puyo's (1948) or Géry's (1959) descriptions is found in French Guiana, according to a broad fish survey made in this territory (Planquette et al., 1996). In addition, a recent revision of Roeboexodon (Lucena \& Lucinda, 2004) recognized a single species (their $R$. geryi), occurring in rivers draining the Guyana and Brazilian Shields. Our observations on material from Surinam, French Guiana, and several tributaries of the Brazilian and Guyana Shields in brazilian Amazon (rio Jari, rio Tocantins, rio Xingu, and rio Tapajós basins), confirm the conclusion reached by Lucena \& Lucinda (2004). Admittedly, not finding a second species for that region is not proof of its inexistence, but it is certainly well beyond the reasonable to conclude, as Myers (1960) and Lucena \& Lucinda 2003) did, that a second species should exist, based merely on a poor, inaccurate original description.

The data presented above thus indicate that it is unreasonable to consider the specimens examined by Puyo (1948) and by Géry (1959) as not conspecific. Myers (1960) believed that they might represent distinct species based on the wrong premise that the innacurate description and the poor drawings provided by Puyo (1948) were a reliable source of information, and based on this mistaken view created a new genus and species where none of that was necessary. Puyo's descriptions are well known to be inaccurate, as discussed elsewhere in the literature (Kullander \& Nijssen, 1989: 171-172; Vari, 1992: 37; Vari \& Harold, 2001: 43; Zanata \& Toledo-Piza, 2004: 113).

Nomenclatural problems. Besides the taxonomic problem discussed above, Lucena \& Lucinda (2003) questioned the proper establishment of the neotype of Exodon guyanensis by Géry (1959). Their conclusion derives from the general purpose, and the qualifying conditions for the establishment of neotypes, outlined by article 75 of the nomenclature code (ICZN, 1999). In their view, these conditions were not met, which rendered the establishment of the neotype invalid.

This problem is of great importance, since if the neotype is deemed valid (i.e., follows all the qualifying conditions [art. 75.3]), it can only be invalidated (for any sort of problems, including taxonomical ones) by the rediscovery of the holotype or by appealing to the International Commission of Zoological Nomenclature. Lucena \& Lucinda (2003) suggested that the main objective of Géry (1959) was the designation of a neotype for Exodon guyanensis, and cited article 75.2 (ICZN, 1999) which states that "neotype is not to be designed as an end in itself, or as a matter of curatorial routine, and any such neotype designation is invalid". They, therefore, concluded that the Géry's neotype designation is invalid. Although Géry (1959) stated in fact that one of the purposes of his paper was to "assign a neotype for Exodon guyanensis and to make an illustrated redescription", it is clear that he presented a redescription for the species because "although [the species] appear clearly defined and illustrated by Puyo" (probably only intended as a polite remark), Puyo's description was "incomplete and no types were assigned" (Géry, 1959: 345). 
Although Géry (1959) did not openly criticized Puyo's (1948) description, he was obviously aware about its shortcomings (p. 345, 351). Ironically, though the arguments provided by Géry (1959) for the designation of a neotype for Exodon guyanensis might appear to be questionable, the unnecessary taxonomical and nomenclatural actions advocated by Myers (1960) and Lucena \& Lucinda (2003) appear to have vindicated his action, i.e., that the designation of a neotype was in this case in fact necessary for nomenclatural stability.

The General Recommendations of the ICZN (1999, appendix B), in referring to stability of nomenclature, specifically state that "... it is of special importance that a name should not be transferred to a taxon distinct from that to which it is generally applied", and "[i]f the provisions of the code appear to require an action which might threaten stability or cause confusion, that action should not be taken before referring the case to the Commission for advice". Thus the Cloffsca check-list, which includes Lucena \& Lucinda (2003)'s commentary clearly does not qualify as a proper publication for this type of nomenclatural action, which should have been instead submitted to the ICZN. In light of this situation, we strongly recommend that the neotype of Exodon guyanensis, designated by Géry (1959), should be considered valid; that the genus Gnathoplax should be considered an objective junior synonym of Roeboexodon; and that Roeboexodon geryi should be considered an objective junior synonym of Exodon guyanensis.

Comparative material. All material from the fish collection of the Museu de Zoologia da Universidade de São Paulo, São Paulo (MZUSP), National Museum of Natural History, Smithsonian Institution (USNM), or Muséum National d'Histoire Naturelle, Paris (MNHN). Roeboexodon guyanensis: Brazil, Tocantins River basin - MZUSP 52123 (44, 2 c\&s), MZUSP 40373 (2); Jari River basin - MZUSP 101984 (1), MZUSP 101982 (22), MZUSP 101800 (1), MZUSP 101981 (2), MZUSP 101983 (16). Surinam, Suriname River basin - MZUSP 10669 (1), MZUSP 10668 (1); Corantijn River basin - USNM 221184 (2), USNM 225238 (1), USNM 221179 (1). French Guiana, Mana River basin - MNHN 1998-1740 (1); Maroni River basin - MNHN 2000-6150 (2 of 4), MNHN 2000-6246 (1 of 2), MNHN 19981860 (1 of 2), and MNHN 2000-6312 (2 of 5), USNM 179755 (1).

\section{Acknowledgements}

The manuscript benefited from comments by Maria Isabel Landim, Naércio Menezes, Richard Vari, and Mônica ToledoPiza. We are grateful to Guy Duhamel and Patrice Pruvost (MNHN) for the loan of material in their care, to David Catania for hospitality and assistance during the stay of CRM in the California Academy of Sciences funded by the Lakeside Foundation. Maria Isabel Landim assisted in the translation of the papers of Puyo and Géry, and Ubirajara Martins assisted on the question of the validity of the Géry's neotype. Finally we thank Carlos Lucena for discussions on the Roeboexodon/ Gnathoplax problem.

\section{Literature Cited}

Eschmeyer, W. N. \& R. Fricke (Eds.). Catalog of Fishes electronic version (Accessed September 9, 2009). http://research.calacademy.org/ ichthyology/catalog/fishcatmain.asp.

Géry, J. 1959. Contributions a l'étude des poisons Characoides (Ostariophysi) (II.) Roeboexodon gen. N. de Guyane, redescription de R. guyanensis (Puyo, 1948) et relations probables avec les formes voisines. Buletin du Muséum National d'Histoire Naturelle, (Série 2) 31(4): 345-352.

Géry, J. 1977. Characoids of the world. New Jersey, T. F. H. Publications, 672p.

Günther, A. 1859. Catalogue of the fishes in the British Museum. Catalogue of the acanthopterygian fishes in the collection of the British Museum Cat. v. 1.

ICZN [International Comission on Zoological Nomenclature]. 1999. International Code of Zoological Nomenclature, Fourth edition. London, The International Trust for Zoological Nomenclature, $306 \mathrm{p}$.

Kullander, S. O. \& H. Nijssen. 1989. The Cichlids of Surinam. Teleostei: Labroidei. Leiden, E. J. Brill, 288p.

Lima, F. C. T., L. R. Malabarba, P. A. Buckup, J. F. P. Silva, R. P. Vari, A. Harold, R. Benine, O. T. Oyakawa, C. S. Pavanelli, N. A. Menezes, C. A. S. Lucena, M. C. S. L. Malabarba, Z. M. Lucena, R. E. Reis, F. Langeani, L. Casatti, V. A. Bertaco, C. Moreira \& P. H. F Lucinda. 2003. Genera incertae sedis in Characidae. Pp. 106-169. In: Reis, R. E., S. O. Kullander \& C. J. Ferraris Jr. (Eds.). Check List of the Freshwater of South and Central America. Porto Alegre, Edipucrs, 729p.

Lowe-McConnell, R. H. 1991. Natural history of fishes in Araguaia and Xingu Amazonian tributaries, Serra do Roncador, Mato Grosso, Brazil. Ichthyological Exploration of Freshwaters, 2(1): 63-82.

Lucena, C. A. S. \& P. H. F. Lucinda. 2004. Variação geográfica de Roeboexodon geryi (Myers) (Ostariophysi: Characiformes: Characidae). Lundiana, 5(1): 73-78.

Myers, G. S. 1960. The South American characid genera Exodon, Gnathoplax, and Roeboexodon, with notes on the ecology and taxonomy of characid fishes. Stanford Ichthyological Bulletin, 7(4): 206-211.

Planquete, P., P. Keith \& P. -Y. Le Bail. 1996. Atlas des Poissons D'Eau Douce de Guyane (Tome 1). Collection du Patrimoine Naturel. Vol. 22. Paris, Museum National d'Histoire Naturelle, Ministère de 1'Environnement, 431p.

Puyo, J. 1948. Deux poisons de la Guyane. Bulletin de la Société d'Histoire Naturelle de Toulouse, 83(1-2): 78-82.

Vari, R. P. 1992. Systematics of the Neotropical characiform genus Cyphocharax Fowler (Pisces: Ostariophysi). Smithsonian Contributions to Zoology, 529: 1-137.

Vari, R. P. \& A. S. Harold. 2001. Phylogenetic study of the Neotropical fish genera Creagrutus Günther and Piabina Reinhardt (Teleostei: Ostariophysi: Characiformes), with a revision of the Cis-Andean species. Smithsonian Contributions to Zoology, 613: 1-239.

Zanata, A. M. \& M. Toledo-Piza. 2004. Taxonomic revision of the South American fish genus Chalceus Cuvier (Teleostei: Ostariophysi: Characiformes) with the description of three new species. Zoological Journal of the Linnean Society, 140: 103135.

Accepted January 27, 2011 Published June 30, 2011 